\title{
Economic Surgery: Money Value Transfer and Storage
}

\author{
Franklin Chiemeka Agukwe \\ Finance Section: Skymax Integrated Networks Limited, Yola, Adamawa, Nigeria \\ Email: eme4ever1234@gmail.com
}

Received 10 March 2016; accepted 25 March 2016; published 29 March 2016

Copyright (C) 2016 by author and OALib.

This work is licensed under the Creative Commons Attribution International License (CC BY). http://creativecommons.org/licenses/by/4.0/

(c)

\begin{abstract}
This paper is an attempt to create a system that could help minimize the rate of borrowing by developing nations through a system known as MVTS. MVTS is a system that is similar to the Gold Standard. It seeks to apply the Gold Standard system in a currency form that transfers and stores the value of foreign currency of high value into a created domestic currency of low value so that money value of created domestic currency can be boosted through its conversion to a foreign currency of high value. In this paper three issues are being focused on which are, money value transfer and storage, tackling any possible threat posed by MVTS and benefits of MVTS.
\end{abstract}

\section{Keywords}

Economic Surgery, Borrowing, Debt, Money Value Transfer and Storage, Money Velocity and Foreign Currency

\section{Subject Areas: Monetary Economics}

\section{Introduction}

Finance is one of the building blocks of modern society, spurring economies to grow. Without finance and without debt, countries are poor and stay poor (Cecchetti, Mohanty and Zampolli [1]). Money is the lifeblood of welfare. A poor welfare is an evidence of an ailing economy. The importance of money is such that the lack of it inevitably leads to borrowing. Borrowing on the other hand has negative impacts which contribute to the backwardness of developing countries. According to (Cecchetti, Mohanty and Zampolli [1]) too much debt for a country impairs the government's ability to deliver essential services to its citizens. The issue here is curbing rising debt. When debt ratios rise beyond a certain level, financial crises become both more likely and more severe (Reinhart and Rogoff [2]).

\section{Significance of This Paper}

What would it feel like for a prisoner who has been in prison for years to suddenly figure out a way of getting

How to cite this paper: Agukwe, F.C. (2016) Economic Surgery: Money Value Transfer and Storage. Open Access Library Journal, 3: e2454. http://dx.doi.org/10.4236/oalib.1102454 
freedom legally? How will it feel for a cancer patient to suddenly discover a way of out of his predicament? Finally how will it feel for a poor country to discover what it takes to live beyond the reach of debt and financial bankruptcy? The significance of this paper is in the same vein. This paper intends to create an easy way out for developing nations to be able to live almost beyond the reach of debt.

\section{Debt Dilemma of Developing Countries}

Cecchetti, Mohanty and Zampolli [1] examined the debt profile of 18 OECD countries from 1980 to 2010. Their results showed that, beyond a certain level, debt is bad for growth. Their result for government debt has the immediate implication that highly indebted governments should aim not only at stabilizing their debt but also at reducing it to sufficiently low levels that do not retard growth. Unfortunately this is the point where most African countries find themselves. High national debt can seriously slow economic growth (Furth [3]). Slow growth is in important respects worse than a recession-it lowers incomes and well-being permanently, not just temporarily. Among the unpleasant features of debt is that it is easy to grow and difficult to shrink. Thus, a one-time increase in government debt is typically a permanent addition, and the drag effects on the economy are long-lasting. Short-term policies can dramatically affect long-term growth (Furth [2]).

Russel [4] also highlights the impacts of public debt on the ordinary citizen. According to him more government debt is generally viewed as a bad side-effect of public policy. He notes that whatever it may be that someone is saving for, whether it is as cheap as groceries or as expensive as college tuition, government debt makes it more difficult to achieve financial goals in turn, that harms quality of life. Langille [5] states that the everyday harm of government debt is widespread, but much of it goes unnoticed. In his words "In the immediate term, the impact of government spending can be harder to feel than taxes or regulations, but it is just as insidious". According to (Antle III [6]) growing federal debt warrants a great concern. According to Lekomola [7], the size of external debt of LDC's was relatively smaller prior to the early 1970's. Lekomola [7] stated that at this period debt was mainly an official phenomenon. He stated that creditors at this period comprised mainly of foreign governments and financial institutions including the World Bank and several regional development banks. He provides a World Bank Report that shows the level of indebtedness of African nations.

As provided by Lekomola ([7], p. 2) the Table 1 shows the initial growth in LDC's loans between 1970 to early 1980's.

From Table 1, we notice that loans from official creditors to LDCs grew by 7 times between 1970 and 1983 . Remarkably, loans from commercial banks expanded 17 times from US\$20 billion in 1970 to US\$335 billion in 1983, which represents more than half of LDCs debt. A World Bank report [8] states that the combined stock of developing countries 'external debt rose from \$4.4 trillion in 2010 to $\$ 4.9$ trillion at the end of 2011, reflecting net debt inflows of $\$ 464$ billion, the upward effect of the year on year appreciation, vis-à-vis the U.S. dollar, of foreign currencies in which around one-third of developing countries external debt is denominated, and debt forgiveness amounting to $\$ 4$ billion. Short-term debt was the fastest growing component, rising by 18 percent in 2011 as compared to a 9 percent increase in the stock of outstanding long term external debt.

According to world hunger [9] website the international debt crisis became apparent when in 1992 Mexico announced it could not pay its foreign debt, thus sending shock waves throughout the International financial community as creditors feared that other countries would do the same. According to UNDP heavily indebted poor

Table 1. Long-term debt of LDC’s by source-selected years (US \$Billions).

\begin{tabular}{ccccc}
\hline Sources & $\mathbf{1 9 7 0}$ & $\mathbf{1 9 8 3}$ & \% Increase & No of Increase \\
\hline 1. Official Creditors & 32 & 221 & 590 & 7 \\
Multilateral & 7 & 80 & 1042 & 41 \\
Bilateral & 25 & 141 & 464 & 6 \\
World Bank & $(2)$ & $(37)$ & 1750 & 19 \\
2. Commercial Banks & 20 & 335 & 922 & 17 \\
3. All sources & 63 & 644 & 1575
\end{tabular}

Sources: World Bank, world debt tables 1989-90, Vol. 1, pp. 378-379. 
countries have higher rates of infant mortality, disease, illiteracy, and malnutrition than other countries in the developing world. The third world has long been recognized as a major obstacle to human development [10]. Shah [10] pointed that many other problems have arisen because of the enormous debt that third world countries owe to rich countries which impeded sustainable human development, security and political or economic stability.

\section{Africa's Debt Dilemma}

Jackson [11] revealed the alarming rate of increased debt of African nations. In his online write up "The African Crisis: Drought and Debt" he stated that foreign debts of African nations has increased so rapidly in recent years that threats of bankruptcy hover across the continent, thus raising the prospects that Africa's most serious crisis will be triggered not by drought, but by debt. According to Jackson [11], the debt problem is not only slowing economic growth and increasing poverty; it is also fomenting political upheaval by forcing African nations to neglect social and economic development in order to make debt payments. According to Giugale [12], when African countries gained independence in the 1960's, they inherited little or no public debt and this continued until the early 1980's. Giugale [12] noted that African countries went on borrowing binge. He observed that by mid 1990's, the average African nation owed more than the value of all the goods and services it could produce in a year. In his words the loans which had to be paid back in foreign currency, came mostly from foreign governments and multilateral institutions and not from private bankers. According to Giugale [12], the loans were for capital projects which was expected to speed up development and create the capacity to repay loan which sounded sensible. However that capacity to repay never really materialized. The international debt crisis has continued to worsen since it erupted in the early 1980's (Kaya [13]). According to Kaya (2005) African countries are caught in a debt trap. A UNICEF Report points out that as African governments are diverting resources away from health, education and other social services to repay foreign debt created by prior rulers put in power by Western powers to suit their interests, the most affected are poor rural women and children including their environment. Jubilee Research a website [14] indicated that each year African countries pay the West nine times more in debt repayments than they receive in grants. Of the 32 countries classified as severely indebted low income countries, 25 are in sub Saharan Africa (Kaya [13]). According to Kaya, Africa spends four times as much on debt repayment as she does on healthcare and this enormous debt means that repayments to Western creditors take priority and ordinary people suffer in poor health, restricted access to education, lack of employment and limited ability to trade and provide for themselves. Kaya went further to reveal the severe consequences of debt in some HIPC's (Highly Indebted Poor Countries). He states that in several HIPCs in Southern Africa such as Zambia. Malawi and Mozambique, over one third of the population is not expected to reach the age of forty. He noted that almost $50 \%$ of the population in these countries lacks access to clean water and sanitation. Despite the measures implemented by the international community to alleviate the Third World debt crisis of the 1980s, which overall have proved very successful in addressing the debt-related problems of many Asian and Latin American countries, a large number of sub-Saharan African countries continue to be faced with volumes of external debt they can ill afford to service [15].

As provided by Lekomola ([7], p. 2), Table 2 represents Africa's total external debt between 1970 and 2007.

Table 2 represents Africa's total external debt between 1970 and 2007. It shows that Africa's external debt increased from US\$9.8 billion in 1970 to US\$123 billion in 1980, US\$288 in 1990 and about US\$195 billion in 2007. In other words, Africa's external debt grew more than ten times between 1970 and 1980 and almost three times between 1980 and 2007. Furthermore, a slight decrease is noticed in 2007 which might be due to the debt cancellation or debt forgiveness.

Table 3 explaining Figure 1 shows the sources of loans for Nigeria from 2005-2014.

Table 2. African total external debt and debt service (US \$ Billions).

\begin{tabular}{rccccc}
\hline Debt Component & $\mathbf{1 9 7 0}$ & $\mathbf{1 9 8 0}$ & $\mathbf{1 9 9 0}$ & $\mathbf{2 0 0 0}$ & $\mathbf{2 0 0 7}$ \\
\hline Total External Debt & 9891 & 123,338 & 288,773 & 211,248 & 195,094 \\
Total Debt Service & 1002 & 18,977 & 27,737 & 29,740 & 27,600 \\
\hline
\end{tabular}

Source: ADB, African development reports, 1993, 2000 and 2007. 

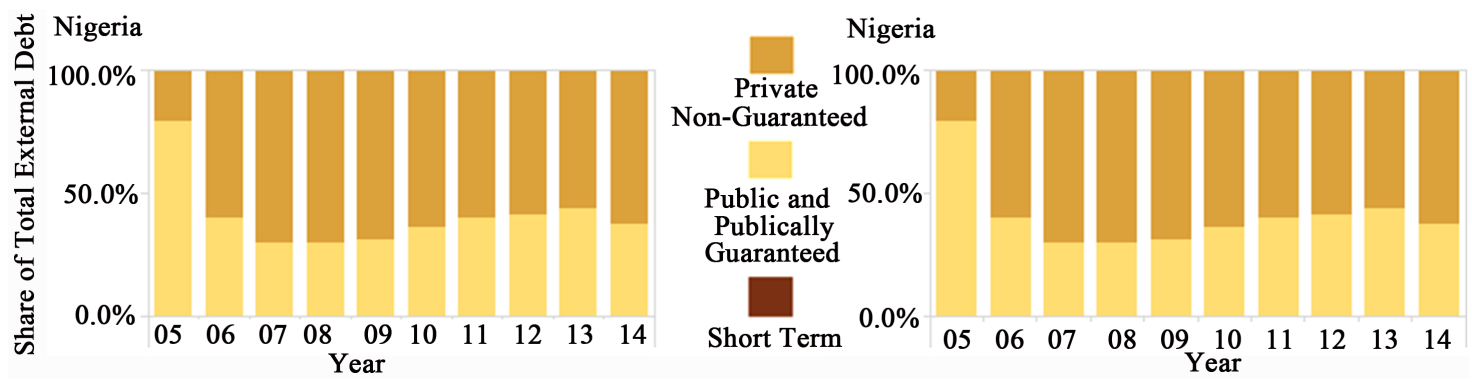

Figure 1. Nigeria's share of total external debt. Source: World bank debt data.

Table 3. Explanation of Figure 1.

\begin{tabular}{ccccc}
\hline YEAR & PRIVATE NON GUARANTEED & $\%$ & PUBLIC AND PUBLICALLY GUARANTEED & $\%$ \\
\hline 2005 & \$25.53 Billion & 20.7 & \$25.53 Billion & 79.3 \\
2006 & \$9.28 Billion & 59.8 & \$9.28 Billion & 40.2 \\
2007 & \$11.78 Billion & 70.3 & $\$ 11.78$ Billion & 29.7 \\
2008 & \$12.79 Billion & 70.3 & $\$ 12.79$ Billion & 29.7 \\
2009 & \$13.23 Billion & 68.7 & \$13.23 Billion & 31.3 \\
2010 & \$12.84 Billion & 64.0 & $\$ 12.84$ Billion & 36.0 \\
2011 & \$14.84 Billion & 60.3 & $\$ 14.84$ Billion & 39.7 \\
2012 & \$16.24 Billion & 59.1 & $\$ 16.24$ Billion & 40.9 \\
2013 & \$19.04 Billion & 56.5 & \$19.04 Billion & 43.5 \\
2014 & \$24.43 Billion & 62.6 & \$24.43 Billion & 37.4 \\
\hline
\end{tabular}

In analyzing the effects of Africa's debts Lekomola ([7], p. 5) pointed to three important factors that warrant attention which are

1. The question of increases in the interest burden, which often exceeds increase in the national income

2. The issue of debt as a proportion of national income rising

3. The consideration of the ratio of debt service payments to export earnings.

He concludes that the fact remains that many highly indebted countries, especially those in Africa have found themselves absorbed in a vicious circle in which their economic growth have been sacrificed for the payment of debt. Regrettably, the sacrificed economic growth is expected to be sine-qua-non of escaping from the debt. Perhaps more worrisome is the view that the prevailing economic decline is almost becoming self perpetuated, to expand that a seemingly low level of living experienced in the late 1970s are becoming luxurious in recent times.

However these cases maybe, the issues as highlighted by various organizations and individuals indicates that debt is adversely affecting not only Africa but other developing countries as well. The question now becomes whether a country can do without debt at least to a very minimal level? At this point we try to answer this question by introducing a concept that is similar to the Gold Standard known as Money Value transfer and Storage

\section{Money Value Transfer and Storage}

MVTS is carried out under three basic assumptions.

1. Every currency in use is created by government and validated by the market.

2. Every currency can be converted to other currencies.

3. A currency of low value can be boosted by its conversion to a currency of high value for a specified period (when in use in its converted currency) in other to stabilize its original value after its conversion back to its original self.

\section{The Hypothesis}

If all currencies are created, then it means that all currencies can be created at any point in time. 


\section{Concept and Definition of MVTS}

From the following assumptions and hypothesis we therefore prove that (in severe cases) money can be created out of thin air whose value can and should be boosted. A currency with low value can be boosted by it's conversion to a currency of high value whose validity is decided by the market. This boosting takes place when a converted currency is used by the government to pay the domestic economy. Thus for the created domestic currency's low value to be boosted and stabilized, the domestic economy must reconvert the converted currency (the dollar) back to its original self the created domestic currency for use. For instance if the Naira is converted into dollar the boosting of the Naira takes place when the currency it is converted to (the dollar) is used by the government to bail out its economy. When government uses the money to bail out the domestic economy the value of the Naira will become stable after the reconversion of the dollar back to the Naira by the domestic economy for use. In other words only the government issues out the dollar at such period domestically. The domestic economy can only use this money (the dollar) after its reconversion back to the local currency the Naira. Government uses the money (the dollar) to bail out its economy without directly adding this money to its treasury (after its creation) because the money has not been validated by the market. It is the use of this money (after its reconversion from the dollar back to the Naira) by the domestic economy (the market) that validates this money which government can now add to its treasury through the fees, levies and other means of generating revenues that the domestic economy will remit to the government. Therefore Money Value transfer and storage is a technique where by government will print a certain amount of money (instead of resorting to borrowing) needed at that moment and convert it to a foreign currency of high value such as the dollar or Pounds Sterling. Thus the value of the foreign money is transferred to and stored in the created domestic currency which empowers the created domestic currency. Therefore if dollar is the converted currency, then the value of the dollar is transferred and stored in the created domestic currency which strengthens the value of the created domestic currency. Government will not add this money to its treasury because it has not been validated by the market. Government can only add this money to its treasury only when the money has been validated by the market. The table below shows this technique.

Table 4 is a summary of MVTS technique. In column E government does not include $\$ \mathrm{M}^{\mathrm{M}}{ }_{1,2}$ but separates it from its treasury $(\lambda)$ because $\$ \mathrm{M}_{1,2}^{\mathrm{M}}$ has not been validated by the market forces of demand and supply. The Figure 2 shows the stage $\$ \mathrm{M}_{1,2}^{\mathrm{M}}$ will be added to the treasury $(\lambda)$.

MVTS (taking account of a precarious situation) intends to create money out of thin air which is why Andresen [16] stated that "there will be negligible opposition in a depressive situation if a government hires more people and buys more goods and services, with brand new HPM (High Powered Money), created out of thin air at the CB (Central Bank) - not even by borrowing. Such policy is possible with an MMT understanding

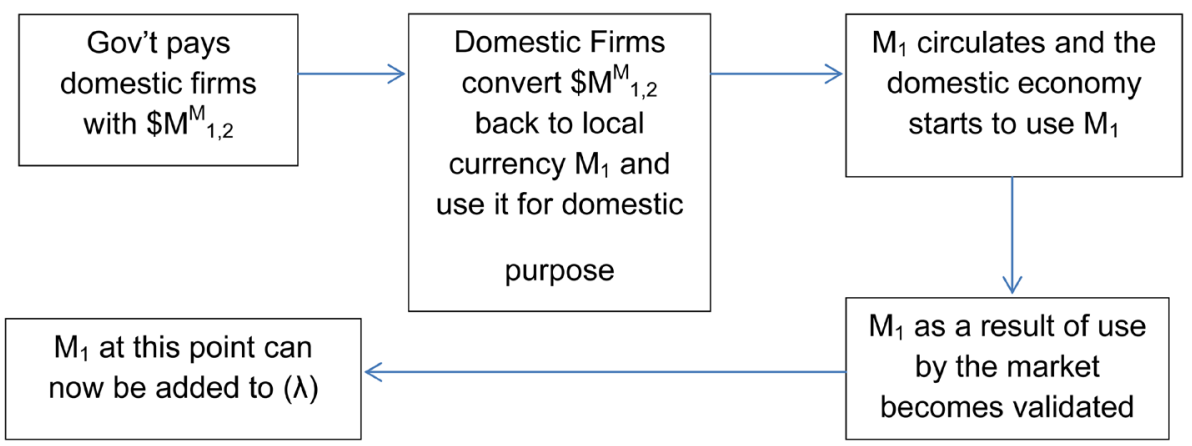

Figure 2. Validation of $\$ \mathrm{M}_{1,2}^{\mathrm{M}}$ by the market.

Table 4. MVTS technique at a glance.

\begin{tabular}{ccccc}
\hline A & B & C & D & E \\
\hline $\begin{array}{c}\text { Created Money } \\
\text { In } \mathrm{M}^{\mathrm{n}} \text {,s }\end{array}$ & Foreign Currency & $\mathrm{M}_{1}$ converted to & $\begin{array}{c}\text { Value of } \$ \mathrm{M}_{2} \text { transferred } \\
\text { and stored in } \mathrm{M}_{1}\end{array}$ & $\begin{array}{c}\text { Gov’t separates } \$ \mathrm{M}^{\mathrm{M}}{ }_{1,2} \\
\text { from its treasury }(\lambda)\end{array}$ \\
$\mathrm{M}_{1}$ & $\$ \mathrm{M}_{2}$ & $\mathbf{S M}_{1,2}^{\mathrm{M}}$ & $(\lambda)-\left(\$ \mathrm{M}^{\mathrm{M}}{ }_{1,2}\right)$ \\
\hline
\end{tabular}


of macroeconomics. In such a situation, people will gratefully accept this, in spite of alarms from deficit hawks and some financial pages pundits." Caution is been raised here which warns that MVTS is not done all the time but in rare cases that calls the need for it.

\section{Importance of Currency Conversion and Reconversion}

The conversion of created local currency of low value to a foreign currency of high value and its subsequent reconversion back to its original self is extremely important because it not only stabilize and keep the original value of the created money to be in exact measure with the value of already existing currencies in circulation it also compresses large quantity of money into small quantity which prevents speedy money velocity, thus created money won't go out and cause problem to the money already in circulation.

\section{Importance of MVTS}

Debts accumulate because of negligence of financial responsibilities for a long time. When financial responsibilities are left unattended to for a long time the resource to take care of them becomes stretched out, thus MVTS ensures that financial responsibilities are taken care of bit by bit, stages by stages so that financial responsibilities won't be abandoned and accumulate.

\section{How to Tackle the Threat Posed by MVTS.}

Inflation remains the biggest threat to the actualization of MVTS. However we tackle this threat with the work of Trond Andresen [16]. Andresen published a highly influential paper titled "Improved macroeconomic control with electronic money and modern monetary theory" This work provides an effective system that can eliminate or minimize inflation. In his Modern Monetary Theory he highlights how electronic money systems offer a big step forward for macroeconomic control, among other things by giving a government new and potent steering tools. His work discusses how electronic money can easily curb an overheated economy.

Andresen [16] based his argument on the fact that curbing inflation is best achieved through control of money velocity - not money supply. An e-payment system curbs money velocity which no doubt is responsible for inflation. He argues that "running necessary large and persistent government budget deficits in depressed economies, is not "irresponsible" and does not need to imply strong inflation in later economic boom situations." He says that through taxation and other methods inflationary pressures can effectively be taken care of within an MMT paradigm. Citing Krugman (2013) Andresen states “It's true that printing money isn't at all inflationary under current conditions - that is, with the economy depressed and interest rates up against the zero lower bound. Today it is technically feasible to discard physical money completely—no bills and coins—and do all transactions by debit card, personal computers (both quite common in developed countries), and/or via the mobile phone network-not common, but on the rise. He cites (Hughes and Loonie, 2007) statement which says that mobile phone money transfers have a proven track record, for instance "M-Pesa" in Kenya. With electronic money ("EM") all transactions are reflected in movements between accounts (Andersen [16]). Andresen further highlighted the advantages of having an electronic money system which are

1. The system is very cheap to run, compared to a system with bills and coins.

2. Adjustments that turn out to be needed, can be implemented in software, therefore very easily and cheaply. No cumbersome and expensive printing/stamping and distribution of bills and coins.

3. Forgery is impossible. So are robberies.

4. This is a $100 \%$ reserve system. All deposits are HPM (base money), at the CB (or ND). No deposit insurance needed. Money cannot be lost, and this is clear to the public. No bank runs.

5. EM is an extremely inclusive and convenient system, giving poor and rural sectors of an economy-where ATMs and bank branches may be far between and not all people have accounts—a tool for easy economic participation and exchange.

6. A black economy in EM is close to impossible. The same with tax evasion. Intelligent software can monitor transactions 24/7, and flag human operators when suspicious patterns emerge. Knowledge of this implies a credible threat, so that agents to a significant degree will abstain.

7. EM cannot be used for capital flight, since it only resides at the CB (or ND). All foreign transactions are logged and thus controllable, as suggested in the previous point. 
8. Negative interest on money held (demurrage) may be easily implemented, to speed up circulation if that is needed.

9. A new possible control tool with the opposite effect is feasible by money only existing as accounts at the CB (or ND): A tiny but adjustable transfer tax between any accounts. This would be incredibly more effective to damp an overheated economy, than today's blunt tool of a CB interest rate increase. It can stop too much spending in its tracks.

\section{Spending Control}

As stressed by Andresen [16], money velocity is a crucial factor. He states that demand in an economy is not decided by the aggregate money supply (a stock), but by the aggregate of money flows $\mathrm{Y}$, where $\mathrm{Y}$ is GDP in which in a continuous-time modeling framework, the denomination of $\mathrm{Y}$ is [\$/year], as opposed to $\mathrm{M}$ [\$].

Andresen [16] noted that in the equation $\mathrm{Y}(\mathrm{t})=\mathrm{M}(\mathrm{t}) \mathrm{v}(\mathrm{t})$ where $\mathrm{M}$ is aggregate money stock and $\mathrm{V}$ is aggregate money velocity, monetary economists according to him are wrong about this equation because they tend to ignore V and focus solely on M citing the words of Paul Samuelson (1948; 354) which says "in terms of the quantity theory of money, we may say that the velocity of circulation of money does not remain constant. "You can lead a horse to water, but you can't make him drink." You can force money on the system in exchange for government bonds, its close money substitute; but you can't make the money circulate against new goods and new jobs" Andresen citing (Hudson, 2010) noted how unfortunate it is that most economists are brainwashed with the trivializing formula MV = PT. The idea is that more money (M) increases "prices" (P)—presumably consumer prices and wages. (One can ignore velocity, "V," which is merely a tautological residual.) “T” is "transactions," for GDP, sometimes called "O” for Output. Citing (Fisher, 1933: p. 67). Andresen notes that "free money may turn out to be the best regulator of the velocity of circulation of money, which is the most confusing element in the stabilization of the price level. Applied correctly it could in fact haul us out of the crisis in a few weeks".

\section{Summary}

This paper tries to prove that countries can do either without debt completely or at least to a very negligible level and one way to do that is the implementation of MVTS. Like any other thing in life that has advantages and disadvantages MVTS may also have such but electronic money system as highlighted in the work of Andresen (2013) is a potent tool against any possible side effects of MVTS. After all the various monies out there are all printed thus with the knowledge of MVTS developing economies can take advantage of it to create paths to economic freedom and prosperity. Debt is bad and this paper tries to prove that developing countries can do without it or reduce it to an almost nonexistent level if only they implement the MVTS system. The term economic surgery is a misnomer. Its meaning is not restricted only to this paper alone. Actually every economic solution is an economic surgery but special attention is being given to this word in this paper because it is believed that the application of MVTS system will be an addition to the various existing economic surgeries.

\section{Conclusion}

We conclude with the words of Lekomola ([7], p. 6) which says the time has arrived for the entire world (debtors and creditors) to see the global debt crises as a joint responsibility for one and all. The entire world economy will fare better if the world's economic playing field is leveled to an extent. As one Professor puts it, "The poor (debtor countries) cannot sleep because they are hungry. The rich (creditor countries) will not sleep because the poor are awake". So a crisis for one is a crisis for all. Less Developed Countries (LDC's) must believe that they have what it takes to live almost beyond the reach of debt. It is a mindset that LDC's must do away with in order to be able to create paths to economic freedom. MVTS is one powerful tool that LDC's can use to achieve this dream. The question here is "is it possible"? The answer is yes, yes and yes it is possible to live almost beyond the reach of debt with MVTS.

\section{Acknowledgements}

Thanks to God the Almighty for making this research a success. I also wish to thank the anonymous reviewers that reviewed this paper, which brought out the best of this paper. My gratitude to them is profound and immense. 


\section{References}

[1] Cecchetti, S.G., Mohanty, M.S. and Zampolli, F. (2011) The Real Effects of Debt. BIS Working Papers No. 352. http://www.bis.org/publ/othp16.pdf

[2] Reinhart, C. and Rogoff, K. (2008) Banking Crises: An Equal Opportunity Menace. NBER Working Papers, No. 14587.

[3] Furth, S. (2013) High Debt Is a Real Drag. www.heritage.org/research/reports/2013/02/how-a-high-national-debt-impacts-the-economy

[4] Russel, J. (2015) Government Debt Can Affect Everything from Grocery Prices to College Tuition. How Government Debt Actually Affects You. www.washingtonexaminer.com/how-government-debt-actually-affects-you/articles/2561062

[5] Langille, S. (2016) Kasich Hopes Positive Approach Will Prevail. www.washingtonexaminer.com/kasich-hopes-positive-approach-will-prevail/article/2582715

[6] James Antle III, W. (2016) Now the Democratic Party’s Establishment Is in Trouble. www.nation.foxnes.com/2016/02/09/now-democratic-partys-establishment-trouble

[7] Lekomola, M. (2010) The African Debt Dilemma: An Overview of Magnitude, Causes, Effects and Policy Options. Journal of American Science, 6, 63-69.

[8] The World Bank (2013) International Debt Statistics. http://datatopics.worldbank.org/debt/

[9] Caritas International and CIDSE; How Did the Debt Crisis Come about? What Was Its Impact on Poor Countries? www.worldhunger.org/articles/global/debt/caritas2.htm

[10] Shah, A. (2007) Causes of the Debt Crisis. http://www.globalissues.org/article/29/causes-of-the-debt-crisis

[11] Jackson, H.F. (1985) The African Debt Crisis: Drought and Debt. https://www.foreignaffairs.com/articles/Africa/1985-06-01/African-crisis-drought-and-debt

[12] Giugale, M.M. (2014) Does Debt Forgiveness Work? Ask Africa. http://www.huffingtonpost.com/marcelo-giugale/does-debt-forgiveness-wor b 5318764.html

[13] Global Issues. The Debt Crisis and Its Effects on African Women and Children. www.globalissues.org/article/225/a-silent-war-the-devastating-impact-of-debt-on-the-poor

[14] Jubilee Research; A Silent War; The Devastating Impact of Debt on the Poor. http://www.globalissues.org/article/225/a-silent-war-the-devastating-impact-of-debt-on-the-poor

[15] All Party Parliamentary Group on Overseas Development (1994) Africa’s Multilateral Debt, a Modest Approach. http://www.odi.org/sites/odi.org.uk/files/odi-assets/publications-opinion-files/8011.pdf

[16] Andresen, T. (2013) Improved Macroeconomic Control with Electronic Money and Modern Monetary Theory. RealWorld Economics Review, Issue No. 63. 